\title{
The Implementation of Problem Based Learning Method in Indonesian Law Education
}

\author{
Saru Arifin \\ Faculty of Law, Universitas Negeri Semarang (UNNES), Indonesia \\ E-mail: saruarifin@mail.unnes.ac.id
}

\begin{abstract}
The legal system in force in Indonesia adheres to the tradition of written law or civil law system. In the tradition of civil law, legal education process organized by the teaching of legal theories as its trademark. By contrast, in the tradition of the common law, legal education is done using the case as it trademark, so that the other terms of the common law is case law. This paper will discuss the use of the problem based learning method in legal education in Indonesia by focusing on two fundamental questions: whether the case method in the legal education system in Indonesia with a tradition of civil law can be done effectively, and what are the factors that needed to be the problem based learning method in legal education with a civil law tradition can be integrated in the curriculum of legal education in Indonesia. This research uses experimental research method in the course of Regional Autonomy Law for students of fourth semester. The results of this study indicate that the use of the case method in the legal education with a tradition of civil law cannot be effectively carried out. This is due to the high burden of student semester credit, little time available, and the difficulty of group work by the students. Accordingly, the use of the case method in legal education with a civil law tradition takes into account changes in the curriculum with course credit load factor, duration and magnitude of college participants.
\end{abstract}

Keywords—Problem Based Learning; the Civil Law System; Legal Education

\section{INTRODUCTION}

One of the factors that influence and determine the quality of the development and the rule of law is the individual quality or Human Resources, so it is natural that more educational institutions focusing attention on issues of human resources quality is the main source of the development process and the rule of law. The quality of human resources closely linked to the quality of higher education law education. Therefore, in terms of education, efforts to improve the quality of law enforcement currently needed reevaluation, reorientation and reform in Indonesian law education ${ }^{1}$.

Higher education law as an integral part of the national education system are actually a part of the effort formation of man and society culture and qualification. College of law cannot be separated from the essence of law enforcement purposes. Particularly in Indonesia where the law education graduated is expected to create a society that is humane, compassionate and fair based on God. In addition, through the law to create a democratic society based on the morality that comes from religious ethics ${ }^{2}$.

Indonesian standards of competence of a Bachelor of Law graduate is having ability to develop insight academic and the professional capabilities, which includes:

1. know the basic of law knowledge to work critically and analysis.

2. mastering the basic skills to do the work of law.

Prabowo, L. 2010. Pendidikan Ilmu Hukum dalam Era Globalisasi, http://hukum.kompasiana.com/2010/05/19/pendidikan-ilmu-hukumdalam-era-globalisasi\%EF\% $80 \%$ AA-oleh-lukmanprabowo\%EF\% $82 \%$ A7/ (accessed on February 13, 2012). Id.
3. has a personality that is based on ethics, morals, and culture of the nation.

4. being able to resolve the legal issues that developed in the community.

5. using the law actively and creatively in social life.

Law education is basically a process of transformation of values and knowledge to the learners, thus learning methods used are very influential on the outcome of the learning process. The learning method of jurisprudence which is conventionally dominated by lectures, only $5 \%$ of them can be absorbed by the students. Other learning techniques, such as: reading $10 \%$, lecture and question and answer $20 \%, 30 \%$ demonstration, group discussion $50 \%$, and $75 \%$ of practice. This suggests that the learning method determines the success of the learning process ${ }^{3}$. Besides less effective in transforming knowledge to the students, the lecture method is seen in some quarters also affect students' critical ability in the face of legal cases in the community, especially when they become a legal practitioner. This, according to Jimly Assiddiqi require a "revolution" in the law education that had been running ${ }^{4}$.

Related to the above, subjects the Law on Regional Autonomy is a new discipline in the disciplines of Constitutional Law. Legally, Autonomous Region began in 2009 with the issuance of Law No. 22 of 1999 on Regional Government. This era also marked the beginning of a new paradigm in the state system of Indonesia from the originally centralized towards de-centralistic. In that context, the

Mitra Hukum, 2012. Metode Alternatif Pembelajaran Hukum, $<$ http://mitrahukum.org/konten.php?nama=Berita\&op=detail_berita\&id $=27>$, (accessed on February 13, 2012).

4 ILRC, 2011. Jimly Asshiddiqie: Lakukan Revolusi Kurikulum Hukum, <http://mitrahukum.org/konten.php?nama=Berita\&op=detail_berita\&id $=62>($ accessed on February 13, 2012). 
regional autonomy in principle give broad authority to local governments to regulate and manage the interests of the local community at its own initiative based on the aspirations of the people in accordance with the legislation.

The main objective of regional autonomy policy issuance, among others, the central government is freed from the burdens of unnecessary in dealing with regional affairs. Thus the opportunity to learn, understand, respond to various global trends and benefit from it. At the same time the central government is expected to be able to concentrate on policy formulation macro (broad or general and basic) national strategic. On the other hand, the decentralized areas will experience optimal empowerment process. The ability of local government initiatives and creativity will be encouraged, so the ability to overcome various problems that occur in the region would be stronger ${ }^{5}$.

Based on the description above, it can be observed that the subjects of Law of Regional Autonomy basically contain matters that are close local wisdom and day life of the community. Therefore, students who take this course are assumed to already have the knowledge and experience sufficient (prior knowledge), so the use of the method of Problem Based Learning (PBL) has possibility high success rate.

\section{LEGAL EDUCATION IN INDONESIA}

Education in Indonesia is growing in parallel with the socio-political dynamics at the national level. Therefore, the legal education in Indonesia is not a process that is autonomous, but rather a process that functionally follow political developments, especially politics that has to do with policy and government efforts to utilize law to achieve the justice ${ }^{6}$.

In general, Sihombing ${ }^{7}$ states that legal education is categorized into two groups, namely: academic and professional. Academic legal education aims to provide legal knowledge to students. Legal education with academic models teach students about what is meant by law, any branch of the law, who is the subject of the faithful and every branch of the science of law, what the principles contained in the law and others. In this context, the legal education is more transfer of knowledge that is theoreticalwhich cannot be applied directly in the real life or the practice of law. As for the professional legal education aims to provide an understanding of how to apply the law properly. Law education is expected with the legal profession, learners have expertise in applying the law ${ }^{8}$.

In the context of global, legal education is divided into two groups, namely the legal education profession generally shared in the system of legal education in the United States. In this model of legal education, the law

Kaloh, 2007.

Sihombing, U.P., et.al., 2009. Mengajarkan Hukum yang Berkeadilan Cetak Biru Pembaharuan Pendidikan Hukum Berbasi Keadilan, Jakarta; ILRC, p.vi, 3. Iskandar and Junaidi, 2011. Memahami Hukum di Indonesia: Sebuah Korelasi antara Politik, Filsafat dan Globalisasi, Cianjur: IMR Press, pp.161., Seran, A., 1999. Moral Politik Hukum, Jakarta: Penerbit Obor, p.43.

Sihombing, 2009. id. p.4-5.

Sihombing, U.P., at. all., 2009. id. p.68. school is for those who will be the legal profession, so that the educational background of various majors of bachelor degree is open. While the second legal education is the education of the general law and adopted by various countries. In this model of legal education, then the requirement is only a high school diploma or its equivalent. In this context, the form of legal education that takes place is an academic legal education. After that, it is for alumni who will continue to pursue legal education profession must take further legal profession education. In this regard, the legal education system in Indonesia in the category of academic legal education ${ }^{9}$.

Historically, legal education in Indonesia began in Jakarta in 1942 which named Rechshshoogeschool. According to Satjipto Rahardjo ${ }^{10}$, the education law at the time was reoriented to advance the interests of the Netherlands, such as filling of Justice personnel, civil servants and work freely. The educational model according to Satjipto Rahardjo called colonial based policy, because it is designed to produce people who will devote the structure and colonial interests in Indonesia.

In such conditions, legal education is taught with the main objective to enable students to master a number of legal principles contained in the legislation that must be understood according to tradition rechslehre Kelsenian reine. The learning process runs as a normative system closed in its use should be considered no logical relationship with the empirical fact that experienced people in the field ${ }^{11}$. This condition persisted in many educational practice law in Indonesia, so the alumni experience stuttering when faced with concrete legal case. This is according Bedner ${ }^{12}$ due to law students in Indonesia are generally only learn about legal theories of various legal writers and little is learned from legal sources such as a judicial decision, the original intents legislation and jurisprudence. This situation is caused by the lack of access against those resources, so that they only know the theory and do not know how to apply them in concrete legal case.

\section{PROBLEM BASED LEARNING METHOD}

\section{a. The Problem Based Learning (PBL) Concept}

Problem Based Learning (PBL) is a learning method that uses an issue as the focus of student's learning activities. At first the PBL method was used to develop the medical curriculum of more than 30 years ago in North America $^{13}$ as Dean and Professor of Law from Murdoch University, explains that this PBL method centered learning

id.

Rahardjo, S. 2009. Pendidikan Hukum sebagai Pendidikan Manusia, Jogjakarta: Genta Publishing, p.27.

11 Wignjosoebroto, S. 2009. Perkembangan Hukum Nasional dan Pendidikan Hukum di Indonesia pada Era Pasca Kolonial, <http:/www.huma.or.id/document/1.03.Analisa Hukum/ Perkembangan Hukum Nasional dan Pendidikan Hukum di Indonesia pada Era Pasca Kolonial_Soetandyo.pdf >, (accessed on February 13, 2012).

12 Bedner, 2013. Indonesian Legal Scholarship and Jurisprudence as an Obstacle for Transplanting Legal Institutions, pp.257, Hague Journal of the Rule of Law, Vol. 5, Issue 02 (2013).p.257.

13 Gabriel A. Moens, 2007. The Mysteries of Problem-Based Learning: Combining Enthusiasm and Excellence, University of Toledo Law Review, Vol. 38, (2007). p.623. 
activities to students and reduce the dominance of the faculty in learning activities. In this context, the lecturer acts as a facilitator. Furthermore, this method of education is recognized by experts as the most important methods used to develop education.

During the period of 20 years running, PBL method has been adopted by several institutions of higher education in countries such as Australia, Europe and America. Other countries that adopt the next as in the field of medicine MacMaster in Canada, and specifically in the field of law adopted by Maastricht University in the Netherlands. While in the field of dentistry, the university has adopted is Adelaide and Queensland in Australia, and is widely used in the social sciences and science ${ }^{14}$.

In the context of law education, Gabriel ${ }^{15}$ explains further, that this method is ideally used for legal education is in essence based on the case. PBL, according to Gabriel, actually have been used in the teaching of law, although some law professors do not admit it. This method is used in the law education intended to make students able to think like a lawyer. One application form PBL method in the science of law known as the acronym MIRAT:

$\mathrm{M}$ - Material Facts-present or absent

I - Issues of law and policy

$\mathrm{R}$ - Rules and Resources

A - Arguments or Application

$\mathrm{T}$ - Tentative Conclusion

MIRAT was used to direct the faculty and students to focus on the material science of law that he/she learned through case studies to find a solution. In this context, there are several steps that need to be considered by the student. First, the students read the material in the form of facts. Second, furthermore, under the guidance of professors, students identify issues relevant to laws and policies. Thirdly, the students further research the legal references and documents relevant to the law issues. Fourth, the next student to discuss the implementation of the resources in a legal case they find. Fifth, is the final step, the students and faculty conduct a thorough formulation of the legal issues that exist as a stimulus.

Flow processes in learning the law to use this PBL method, described by Gabriel ${ }^{16}$ as follows:

a. Problem finding;

b. Preliminary consideration of approaches to the problem;

c. Inquiry strategy;

d. Issue identification;

e. Research;

f. Legal analysis and consideration of solutions; and

g. Counseling or case management

Other forms, student assessment task is the advocacy model, that is the method most widely used by law schools in the world, especially in the United States. However, it difference with PBL method is, that in the advocacy methods, students deliver more arguments orally instead of in writing, as in the PBL method.

Gabriel, 2007. id. P.626

id.p.626.

id. p.627.
Meanwhile, PBL method is a method of lecturebased to the participation of the students. In the first hour lecture, the method applied is the discussion. Lecturers provide questions to the students who were assigned at random. To questions probing their opinions and develop the analytical skills of students. Then, at the last hour, the lecturer gives a summary and the core of the discussion on that day accompanied by a core of material context associated with the implementation in the field.

\section{b. The use of PBL Method in Indonesian Law Education}

As has been described previously about different methods of PBL with conventional methods in educational law practice, then it clearly shows the fundamental difference between legal education with a tradition of civil law and common law. Theoretically the PBL method will have much effect on the practical ability of students to the science of law studied, contrary to the tradition of civil law education which emphasizes a lot more impressive theory that conventional model of legal education. Therefore, with the limitations that exist in the educational tradition of civil law, then in the case of PBL following samples will be analyzed regarding the effectiveness of the PBL method.

Over the span of half of the semester, the practice of Problem Based Learning method performed on students in the field of Regional Autonomy Law. In accordance with the action plan as described above, then the implementation of the PBL method, in chronological order, starting with the preparation, implementation and evaluation. Full description PBL implementation process as follows.

\section{Preparation}

In accordance with PBL concept above, the four stages of preparation of the activities undertaken by the research team. First, start with a lecture delivered to students the syllabus. This activity is of a general nature as usual lectures. Second, the students were grouped into seven groups, with each group consisting of 8-9 people. Third, explore college participants prior knowledge by way of brainstorming in groups. In this activity, the researchers provide the opportunity for each group to discuss issues related to regional autonomy with the name of their respective groups. Observations in such activity, it appears that in general, students who attend lectures regional autonomy law has sufficient prior knowledge. This is because the problems of decentralization are readily found in everyday life, and they see, with or read in the media, especially regarding real cases in the community.

\section{The Implementation of PBL}

During the implementation of activities can be described as follows. First, in the early half of the semester, the researchers delivered material regional autonomy law as an introduction for students to the provision of basic knowledge of the regional autonomy law. This activity is running as lectures in general, but the approach used by the researchers still refer to concept of Student Centered Learning (SCL). In this context, researchers always provide 
opportunities for students to express their opinions related to the topics presented. Technically in each lecture, students in the first hour sitting in general and free. In the next hour, the researchers asked the students to sit in groups.

Activities with the lecture model is intended on two things, namely: when seated freely in the midst of the lecture when researchers express a problem, then the student is paired with a friend sitting next to interchagecheably discussion to respond to the issues thrown up by the researcher. It is intended that each student has the same opportunity to express ideas and knowledge on the issues presented by the researcher. Hopefully, through these activities, each student grow confidence and motivates them to follow the lecture.

Meanwhile, the next hour, the researchers asked each student to sit in groups. It takes about 5 minutes to change the seat and look for other group members. Once the group is ready, the lectures forwarded again to the same topic. Modifications done by researchers at solving the problems submitted by researchers. The nature of problem solving is a collective group, so that each individual has the courage argued in scope in pairs, are expected to split the idea when in a group.

In the group discussion sessions, a technical working group emphasized is the collectivity group. Therefore, the researchers stressed to each group leader to ask the opinion of each of its members, and not give a chance only on certain members. This is not only intended to provide equal opportunities for everyone, as well as to build mutual cooperation as a solid. This, once again is important to build the strength of teamwork in doing the analysis of the case in the later half of next semester.

\section{c. Analysis of PBL Practice}

As discussed earlier, that the PBL method is intended to give participants practical space for lectures on legal theories that have been learned. Therefore, the achievement of learning objectives in terms of understanding the concept and context, and the character development of learners will be described in this section.

First, the effectiveness of PBL in the context of character development cooperation (team work). As we know that in practice the PBL used group method. The results showed a positive response in the character development of cooperation between learners. Data show that students generally prefer the study group (52\%). The next method is to learn individually $(28 \%)$, and the other with a lecture lecturer in the classroom $(20 \%)$.

The data shows that college students love learning method collaboratively with their friends. There are at least two reasons that into consideration why the model of learning in groups is preferred. First, students can learn cooperation with more friends, so if there are issues could be shared with each other. The reason was stated for example by Arif of a group of municipal police ${ }^{17}$ and also Luqman from Regent Group ${ }^{18}$.

Second, the reasons are personal. In this context, the students feel more familiar with other friends, and also

\footnotetext{
Students Focused Group Discussion, 23/05/2012.

Students Focused Group Discussion, 23/05/2012.
}

for those who have not been so familiar to be closer. This situation is certainly a positive impact in the development of social attitudes of students.

Thirdly, the reason most commonly cited is that it can complement each answer with a friend group. The reason is more meaningful as the value of the benefits of cooperation in a group as described above. A case if done together, then the answer will be far better than just working individually, as each member of the group can complementarity. Another plus is that students will be trained to argue in looking at a case from the perspective of knowledge and experience respectively.

In the context of character education, then it is a positive impact in the educational value of cooperation and mutual respect among peers. This condition in the long run will affect the social skills, so as to become a society that has a personality that is polite, tolerant and caring for others. These conditions concern the nation that has increasingly in people's lives. Therefore, through this kind of education they will be familiar with such a positive attitude.

Meanwhile, a similar opinion was also expressed by Jenkins, Antil, Wayne, and Vadasy ${ }^{19}$ explains that the study group will help students learn cooperation and simultaneously evaluate the value of such cooperation. According to him, the cooperation will foster learning two skills at once, namely listening to the opinions of friends and learn with a friend who is not a close friend (different). In the context of legal science lesson, Elizabeth L. Inglehart, Kathleen DN and Clifford $\mathrm{SZ}^{20}$ based on their research suggests that in legal writing lessons, group learning methods have a positive impact in terms of improvement of the material, teaching style, relationship with students as well as classroom setting,

In the PBL through FGD $^{21}$ Honan and Dian of municipal police group firmly recognizes that through case studies in groups, they feel closer to friends, learn to work together, pour aspirations, more compact and active thinking. In this context, the students have managed to capture the meaning of cooperation in a group that had a positive impact in the development of tolerance and common interests above personal interests. It is described by Johnson \& Johnson, as quoted by Richard M. Felder and Brent Rebecca $^{22}$ that the cooperative learning (group work) will have a positive impact in achieving the common goal which is reflected by the following five conditions: interconnectedness is positive, individual accountability, face-to-face interaction (direct), the use of proper cooperation skills, and poses for a group. Five things comprehensively along with its descriptions are as follows:

1. Positive interdependence. Team members are obliged to rely on one another to achieve the goal. If any team

\footnotetext{
19 Jenkins, J.R., Antil, L.R., Wayne, S.K. and Vadasy, P.F., 2003. How cooperative learning works for special education and remedial students. Exceptional children, 69(3), pp.279-292.

20 Inglehart, E.L., 2003. From Cooperative Learning to Collaborative Writing in the Legal Writing Classroom.

21 Students Focused Group Discussion, 23/05/2012.

22 Richard M. Felder and Brent Rebecca, 2007. Cooperative Leraning, ACS Symposium Series 970, Chapter 4, Washington, DC: American Chemical Society dalam www.ncsu.edu/felder-public/.../CLChapter.pdf, (accessed on Februari 13, 2012). p.34-53.
} 
members fail to do their part, everyone suffers consequences.

2. Individual accountability. All students in a group are held accountable for doing their share of the work and for mastery of all of the material to be learned.

3. Face-to-face promotive interaction. Although some of the group work may be parcelled out and done individually, some must be done interactively, with group members providing one another with feedback, challenging reasoning and conclusions, and perhaps most importantly, teaching and encouraging one another.

4. Appropriate use of collaborative skills. Students are encouraged and helped to develop and practice trustbuilding, leadership, decision-making, communication, and conflict management skills.

5. Group processing. Team members set group goals, periodically assess what they are doing well as a team, and identify changes they will make to function more effectively in the future.

Meanwhile, Theodore Panitz straightforwardly outlining the positive sides of cooperative learning in a group, especially in the development of social interaction skills (social interaction skills). According to one of the effects of cooperative learning for students is to foster social attitudes responsive, reducing the occurrence of violence, fear, and cultivate an attitude of hospitality and so on. In that context Theodore insists that the process is as important as the content and purpose (of a study). More Theodore statement is as follows ... " cooperation learning promotes positive societal responses, reduces violence in any setting, eliminates fear and blame, and increases honor, friendliness, and consensus. Process is as important as content and goal ".

Theodore statement that if understood through the reverse logic indicates, that the emergence of a variety of harsh temperament among the people affected by the strong individual character because of the low interpersonal communication has. This is caused by the poor quality of social interaction doing, so cultivate an attitude of individualism in himself and considers his actions as an expression of freedom, without regard to the requirements of morality in the society. In addition, custom individualistic attitude that will give birth to more negative attitudes, such as the truest sense of self in the act, a sense indifferent to the surrounding environment, and tend to be emotionally reactive in the face.

As has been mentioned before, that through the case studies students have the attitudes and behavior are quite enthusiastic in following the lecture. During the observation process lecturing, students have tried to elaborate the various theories related to the subject matter of each, as well as linked with the factual conditions in the field.

In the perspective of adolescent psychology, Professor Malcolm Knowles ${ }^{23}$, based on those observations indicate that there are important things in the way of learning a teenager, namely:

\footnotetext{
Knowles, M. 2012. Case Study-Based Learning: Enhancing Learning Through Immediate Application, dalam http://www.mindtools.com/pages/article/newISS 94.htm, (accessed on February 13, 2012)
}

1. Adults learn best if they know why they're learning something.

2. Adults often learn best through experience.

3. Adults tend to view learning as an opportunity to solve problems.

4. Adults learn best when the topic is relevant to them and immediately applicable.

Subsequently, Knowles confirmed that the models of learning that can produce the best results can be achieved when youth are given the opportunity to be fully involved in the practice sessions and give them the opportunity to practice the skills they have.

Further, Knowles insists that the case study is one of learning-experience involving them actively in studying the theory and practice of simultaneously-with the skills they use. Therefore, according to Knowles, there are four things that can gain in learning with case studies, namely: focus on why and how to apply skills and concepts; opportunity to build study groups; build problem-solving skills; and can be used as a method of evaluating how they solve the problem themselves.

1. Case studies growing niche to focus on why and how to apply a skill or concept, not on remembering facts and details. Use case studies when understanding the concept is more important than memorizing correct responses.

2. Case studies are great team-building opportunities. When a team gets together to solve a case, they'll have to work through different opinions, methods, and perspectives.

3. Use case studies to build problem-solving skills, particularly Reviews those that are valuable when applied, but are Likely to be used infrequently. This helps people get practice with Reviews These skills that they might not otherwise get.

4. Case studies can be used to Evaluate past problem solving. People can be asked what they'd do in that situation, and think about what could have been done differently.

Meanwhile, in relation to the learning with a case study model, stated a similar expression by Claire Davis and Elizabeth Wilcock ${ }^{24}$. Grab his second stated that the emphasis of the case study is to apply the theory or concept into practice in the field; encourage students to actively learn; giving them the opportunity to develop skills such as communication, teamwork and problem solving; A push students toward topics which learnt.

\section{Integration of the PBL curriculum}

In the 2015 curriculum, students are required to achieve equal degree take 144 credits with a material burden perkuliah pretty solid, so there are many teachers who feel that given time is not enough to give the overall course material to students. Components required lecture is composed of three, a doctrine, positive law, and cases. Hopefully, with this kind of basic legal knowledge, the graduates will eventually be able to develop their own skills

\footnotetext{
24 Davis, C. and Wilcock, E., 2005. Developing, implementing and evaluating case studies in materials science. European Journal of Engineering Education, 30(1), p.59-69.
} 
and their skills in the field they pursue after graduation. This expectation seems to have not been met, as reflected in the number of complaints and hold a law graduate.

Complaints submitted by consumers who use law graduates, generally revolve around the limitations of such graduates to immediately be able to work in an institution. Legal skills are expected to appear can not be met through legal education. Such conditions should be understood when consumers are demanding that their graduates 'ready to go,' and instead of 'ready to work.' That legal scholars many do not understand deeply the law of the event, basically is a matter that cannot be removed from the curriculum development occurs. Moreover, coupled with expectations of the lecturers that their graduates will be more learning outside.

Many senior legal scholars who expects that the new recruits understand the law as they used to be. One thing that is overlooked is that the higher education curriculum before 1983 is different from the after-year by the Decree of the Director General of Higher Education No. 30 in 1983. It is of course also brought changes in the curriculum that had been referring to the semester system be Semester Credit System. With the semester system, each subject was given during the course of one year. Being in a system of credits, subjects of Criminal Law, for example, only three hours a week for one semester ( 3 credits). In addition, the courses given to students considerably changed in number and variety.

Decree of the Minister of Education and Culture No. 017 / D / 0/1993 regarding the law school curriculum, as amended by the Education Minister Decree No. 0325 / U / 1994 is an effort to hold reorientation in legal education. Decisions about the curriculum, among others, was taken because of the high level of consumer complaints about law school graduates who they refer to as 'do not pay attention to the needs of the market'. Because it is precisely in this curriculum included one group of subjects are referred to as 'Education and Training of Law Proficiency'.

Efforts to bring legal education to the legal profession is welcomed by all parties of course. Moreover, when viewed destinations legal studies program that prepares students to be law graduates:

a. master the law of Indonesia,

b. master the basic skills of the scientific basis and work to develop jurisprudence and law,

c. recognize and be sensitive to issues of justice and social problems,

d. able to analyze the law in society,

e. able to use the law as a means to solve social problems wisely and based on legal principles.

It should be recognized that the law school is not easy to carry the load as described above. Hope the community to get skilled legal scholars who use the law to resolve the issue (problem solving) has not been fulfilled for a variety of reasons, both internal and external, as stated above. In this context pembelaran case-based legal challenge to get integrated into the lecture, so that the necessary reforms and adjustments-that PBL method can be applied properly in accordance with the parameters and goals to be achieved through the PBL method.

\section{CONCLUSION}

Based on the description in the previous section shows that in general the law by using an approach learning Problem Based Learning (PBL) responded positively by students. They feel more free in reviewing cases assigned topic, both in terms of building a theoretical framework from reading materials, as well as in the context of its application in the field. This process should be in line with a compact group with an early stage of formation of a group that is freely chosen, then the determination of the topic and the assignment of personnel. Such models well appreciated by students, so not only learn theory, but they know how the application of the theory in the field, such as dynamics and shortcomings, so that it becomes a positive input in strengthening the curriculum subjects.

However, considering the number of lectures burden faced by the participants study, this method is distorted theoretical, because the tendency of participants only know the topics he discusses many and few who understand the theory worked out by other groups. This condition is an obstacle in the tradition of legal education with a model-laden civil law and dense with learning demands a lot of legal theory. Therefore, it is necessary to overhaul the curriculum adaptive to the needs of the labor market by selectively incorporate PBL method as the provision of legal practice experience for the students in preparing themselves to enter the work.

\section{REFERENCES}

[1] Bedner, Adriaan, Indonesian Legal Scholarship and Jurisprudence as an Obstacle for Transplanting Legal Institutions, pp.257, Hague Journal of the Rule of Law, Vol. 5, Issue 02 (2013).

[2] Davis, C. and Wilcock, E., 2005. Developing, implementing and evaluating case studies in materials science. European Journal of Engineering Education, 30(1), pp.59-69.

[3] Gabriël A. M., The Mysteries Of Problem-Based Learning: Combining Enthusiasm and Excellence, University of Toledo Law Review, Vol. 38, (2007).

[4] Iskandar, P. dan Junadi, Y., (2011). Memahami Hukum di Indonesia: Sebuah Korelasi antara Politik, Filsafat dan Globalisasi, Cianjur: IMR Press.

[5] Jenkins, Antil, Wayne, and Vadasy, How Cooperative Learning Works for Special Education and Remedial Studies" by Jenkins, Antil, Wayne, and Vadasy, Journal of Exceptional Children, Vol. 69, No. 3, 2003, pp. 279-292, (2003).

[6] Kaloh, J., (2007). Mencari Bentuk Otonomi Daerah, Jakarta, Rineka Cipta.

[7] Knowles, M. Case Study-Based Learning: Enhancing Learning Through Immediate Application, dalam http://www.mindtools.com/pages/article/newISS_94.htm, (diakses tanggal 15 September 2012).

[8] Prabowo, Lukman, Pendidikan Ilmu Hukum dalam Era Globalisasi,

http://hukum.kompasiana.com/2010/05/19/pendidikan-ilmuhukum-dalam-era-globalisasi\%EF\%80\%AA-oleh-lukmanprabowo\%EF\% 82\%A7/ (accessed on February 13, 2012).

[9] Mitra Hukum, Metode Alternatif Pembelajaran Hukum, $<$ http://mitrahukum.org/konten.php?nama=Berita\&op=detail _berita\&id=27>, (accessed on February, 13, 2012). 
[10] Rahardjo, Satjipto. (2009). Pendidikan Hukum sebagai Pendidikan Manusia, Jogjakarta: Genta Publishing.

[11] Richard M. Felder, dan Rebecca Brent, Cooperative Leraning, ACS Symposium Series 970, Washington, DC: American Chemical Society dalam www.ncsu.edu/felderpublic/.../CLChapter.pdf, (accessed on February, 13, 2012). Chapter 4, pp. 34-53.

[12] Seran, Alexander, Moral Politik Hukum, Jakarta: Penerbit Obor, 1999.
[13] Sihombing, U.P., et all., (2009). Mengajarkan Hukum yang Berkeadilan: Cetak Biru Pembaruan Pendidikan Hukum Berbasis Keadilan Sosial, Jakarta: The Indonesian Legal Resources Center (ILRC).

[14] Wignkosoebroto, Soetandyo, 2009. Perkembangan Hukum Nasional dan Pendidikan Hukum di Indonesia pada Era Pasca Kolonial, <http:/www.huma.or.id/document/1.03. (accessed on February 13, 2012). 